\title{
Peningkatan Hasil Belajar PPKn Materi Menganalisis Bentuk-Bentuk Kerjasama Menggunakan Model Student Team Achievement Divison (Stad) Pada Siswa Kelas VII A Di SMP Negeri 1 Gandusari
}

\author{
Sukini \\ SMP Negeri 1 Gandusari \\ Email: kinybeny@gmail.com
}

\begin{abstract}
Abstrak: Penelitian ini bertujuan untuk mengetahui peningkatan hasil belajar PPKn materi menganalisis bentuk-bentuk kerja sama menggunakan model pembelajaran Model Student Team Achievement Divison (STAD) pada siswa kelas VIIA SMP Negeri 1 Gandusari. Tujuan penelitian tindakan kelas dalam penelitian ini adalah untuk mendapatkan gambaran objektif tentang peningkatan hasil belajar PPKn materi menganalsis bentuk-bentuk kerja sama menggunakan. Penelitian ini menggunakan pendekatan kualitatif dan jenis penelitian tindakan kelas yang dilaksanakan di kelas VIIA SMPN 1 Gandusari Penelitian ini dilakukan dalam dua siklus yang masing-masing melalui empat tahapan, yaitu: (1) tahap perencanaan, (2) tahap pelaksanaan, (3) tahap observasi, (4) tahap refleksi. Instrumen pennelitian menggunakan tes tulis uraian. Hasil penelitian menunjukkan bahwa model pembelajaran

\begin{tabular}{l}
\hline Tersedia Online di \\
\hline http://journal.unublitar.ac.id/pendidik \\
an/index.php/Riset_Konseptual \\
\hline Sejarah Artikel \\
\hline Diterima pada : 08-04-2021 \\
Disetuji pada : 10-04-2021 \\
Dipublikasikan pada : 30-04-2021 \\
Kata Kunci: \\
Hasil belajar, keberagaman, Student \\
Team Achievement Divison (STAD) \\
DOI:
\end{tabular}

http://doi.org/10.28926/riset_konseptual.v5i2. 342 dengan menggunakan model Model Student Team Achievement Divison (STAD) dapat meningkatkan hasil belajar PPKn materi keberagaman dalam masyarakat Indonesia siswa Kelas VII A SMP Negeri 1 Gandusari semester 2 tahun pelajaran 2017/2018. Hal ini dapat dilihat dari nilai rata-rata tes siklus I, yaitu 73,85 dan siklus II 85,38 berarti ada peningkatan. Selain itu, ketuntasan belajar pada siklus I, yang tuntas $61,54 \%$ atau 16 siswa sedangkan yang tidak tuntas, 38,46\% atau 10 siswa. Siklus II siswa yang tuntas mencapai $100 \%$.
\end{abstract}

\section{PENDAHULUAN}

Pembelajaran merupakan proses interaksi antara peserta didik dengan lingkungannya. Hasil dari pembelajaran diharapkan adanya kea arah yang lebih baik dalam hal perilaku. Dalam proses pembelajaran guru dituntut aktif dalam menciptakan dan mengembangkan kegiatan peserta didik sesuai dengan rencana yang telah direncanakan sebagai aktualisasi kurikulum yang telah dibuat. Ada dua tingat dalam capaian pembelajaran yaitu tingkat mikro dan makro. Pada tingkat mikro, pencapaian kualitas pembelajaran merupakan tanggung jawab profesional seorang guru, sebagai contoh melalui pengalaman belajar yang bermakna bagi siswa dan fasilitas yang didapat siswa untuk mencapai hasil belajar yang lebih baik. Pada tingkat makro, melalui sistem pembelajaran yang berkualitas, lembaga pendidikan bertanggungjawab terhadap pembentukan tenaga pengajar yang berkualitas, yaitu yang dapat berkontribusi terhadap perkembangan intelektual, sikap, dan moral dari setiap individu siswa sebagai anggota masyarakat.

Umumnya masalah utama dalam proses pembelajaran adalah masih rendahnya daya serap peserta didik. Hal ini dapat dilihat dari rata-rata prestasi belajar peserta didik yang belum sesuai dengan harapan kita atau belum mencapai kriteria ketuntasan minimum. Pembelajaran yang dominan terpusat pada guru menyebabkan 
prestasi belajar yang rendah karena tidak memberikan kesempatan bagi siswa untuk berkembang secara mandiri dalam proses berpikir sehingga keaktifan siswa selama proses pembelajaran masih rendah.

Guru harus dapat mengambil keputusan atas dasar penilaian yang tepat ketika peserta didik belum dapat membentuk kompetensi dasar, apakah kegiatan belajar dihentikan, diubah metodenya atau mengulang dulu pembelajaran yang lalu. Mata pelajaran PPKn juga merupakan kajian yang sangat penting karena bersentuhan langsung dengan kehidupan sehari-hari. Pembelajaran PPKn berkaitan dengan persoalan kehidupan berbangsa dan bernegara sehingga setiap saat digunakan, tetapi disisi lain mata pelajaran ini menjadi sesuatu yang dianggap remeh. Guru PPKn membawa kesan bahwa cara penyampaiannya dengan ceramah mata pelajaran hafaalan. Belum lagi PPKn yang menyajikan banyak pasal-pasal, aturan etika yang berllaku di masyarakat.

Dari pengamatan pra tindakan, dari jumlah 31 siswa, hanya 14 siswa yang memperoleh nilai memenuhi kriteria ketuntasan minimal $(\geq 70)$ atau ketuntasan sebanyak $45,16 \%$. Hal ini menunjukkan bahwa sebagian besar siswa belum mencapai kriteria ketuntasan minimal (KKM) yang ditetapkan sekolah, dan terdapat sebanyak $54,84 \%$ siswa yang belum mencapai indikator dalam proses pembelajaran tersebut.

Hal ini disebabkan karena beberapa faktor, diantaranya selama proses pembelajaran di kelas berlangsung peserta didik masih kurang aktif dalam mengikuti pelajaran, banyak siswa yang melakukan aktifitas lain selain mendengarkan penjelasan oleh guru. Karena proses pembelajaran lebih banyak terpusat pada guru, maka guru lebih dominan menggunakan metode ceramah. Untuk mengatasi hal tersebut maka peneliti menerapkan model student team achievement divisions (STAD) dengan harapan dapat meningkatkan prestasi belajar PPKn materi Menganalisis bentuk-bentuk kerja sama. Model Pembelajaran student team achievement divisions (STAD) merupakan jenis pembelajaaran kooperatif yang didesain seperti kerja kelompok dengan membentuk sebuah team kerja yang kuat. Model pembelajaran ini bertujuan untuk memancing kreatifitas kelompok untuk saling berbagi, membantu temannya memahami materi pelajaran sekaligus menguji daya serap materi yang disampaikan oleh ketua kelompok.

Dalam proses pembelajaran, model pembelajaran memiliki peranan yang penting, karena model pembelajaran sebagai pedoman bagi para guru dalam melaksanakan pembelajaran. Untuk memilih model pembelajaran ini sangat dipengaruhi oleh sifat materi yang akan diajarkan, dan juga dipengaruhi oleh tujuan yang akan dicapai dalam pengajaran tersebut serta kemampuan siswa.

Untuk mengatasi masalah tersebut guru yang baik harus dapat menggunakan model yang tepat. Misalnya dengan menciptakan suasana pembelajaran yang menyenangkan. Pembelajaran yang menyenangkan dapat tercipta bila guru menggunakan model yang bervariasi dan relevan dengan materi yang akan diajarkan. Selain itu, siswa akan merasa tertarik mempelajari PPKn, mencoba, dan membuktikan sendiri, sehingga akan memperkuat kemampuan kognitifnya. Dengan demikian tujuan pembelajaran PPKn dapat tercapai. Berdasarkan latar belakang di atas, peneliti melakukan penelitian ini dengan tujuan untuk mengetahui Peningkatan Prestasi Belajar PPKn Materi menganalisis bentuk-bentuk kerja sama Melalui Model student team achievement divisions(STAD) Pada Siswa Kelas VII A Semester 2 Tahun Pelajaran 2017/2018 di SMP Negeri 1 Gandusari”.

\section{METODE}

Penelitian ini termasuk penelitian dengan menggunakan metode deskriptif kualitatif dengan pendekatan Penelitian Tindakan Kelas dengan dua siklus. Penelitian Tindakan Kelas atau (Classroom Action Research) adalah penelitian tindakan yang dilakukan di kelas dengan tujuan memperbaiki mutu praktik pembelajaran. Menurut Wiriatmadja (2008 : 12) bahwa "Penelitian tindakan kelas adalah kajian sistematik dari 
upaya perbaikan pelaksanaan praktik pendidikan oleh sekelompok guru dengan melakukan tindakan-tindakan pembelajaran".

Proses tindakan yang dilakukan dalam penelitian ini diupayakan agar masalah yang terjadi dapat teratasi, sekaligus untuk meningkatkan prestasi belajar PPkn. Alasan menggunakan metode ini yaitu karena mempertimbangkan masalah yang dihadapi adalah masalah yang timbul dalam proses pembelajaran, tidak mengganggu jalannya pembelajaran sesuai dengan kompetensi yang diajarkan, ingin melihat perkembangan sampai adanya peningkatan kemampuan membaca permulaan anak yang digunakan sebagai subjek peneliti. Penelitian tindakan kelas ini akan dilakukan secara kolaboratif partisipatif, yaitu penelitian dengan melakukan kolaborasi kerjasama antara guru dengan peneliti.

Merujuk pada proses pelaksanaan pembelajaran dengan pendekatan ini yang dikemukakan Kemmis dan McTaggart. Kemmis dan McTaggart dalam Arikunto (2010), mengembangkan modelnya berdasarkan konsep yang dikembangkan Lewin, dengan disertai beberapa perubahan. Dalam perencanaan Kemmis dan McTaggart menggunakan siklus sistem spiral, yang masing-masing siklus terdiri dari empat komponen, yaitu perencana, tindakan, observasi dan refleksi. Kemmis dan Mc. Taggart dalam Arikunto (2010: 16).

\section{Prasiklus/Kondisi Awal}

\section{HASIL DAN PEMBAHASAN}

Kondisi awal yang terjadi pada siswa kelas VII A semester I tahun ajaran 2017/2018 SMP Negeri 1 Gandusari, Kabupaten Trenggalek bahwa nilai rata-rata Pendidikan Kewarganegaraan dianggap belum tuntas secara klasikal, karena nilai ratarata hanya mencapai 62 dengan ketuntasan 48,39\% atau 15 siswa yang tuntas. Sedangkan seorang siswa dinyatakan tuntas belajar pada pokok bahasan atau sub pokok bahasan tertentu jika mendapat nilai minimal 70. Kenyataan di lapangan menunjukkan bahwa ketuntasan klasikal belum mencapai ketuntasan belajar tuntas yaitu bila siswa yang telah tuntas mencapai $85 \%$. Melihat kondisi tersebut peneliti tergerak untuk memperbaiki pembelajaran yaitu dengan melakukan penelitian kelas.

\section{Siklus I}

Tabel 1. Hasil Tes Siklus 1

\begin{tabular}{|l|l|l|l|l|l|}
\hline No & Nilai $(\mathrm{x})$ & Frekuensi & $\left(\mathrm{x}^{*} \mathrm{f}\right)$ & Prosentase & Keterangan \\
\hline 1 & 90 & 4 & 360 & 12.90 & Tuntas \\
\hline 2 & 80 & 13 & 1040 & 41.94 & Tuntas \\
\hline 3 & 70 & 4 & 280 & 12.90 & Tuntas \\
\hline 4 & 60 & 6 & 360 & 19.35 & Tidak Tuntas \\
\hline 5 & 50 & 4 & 200 & 12.90 & Tidak Tuntas \\
\hline & & 31 & 2240 & 100.00 & \\
\hline & Rata-rata & 72.26 & & \\
\hline & Tuntas & 67,75 & 21 & \\
\hline & Tidak Tuntas & 32,25 & 10 & \\
\hline & Nilai Tertinggi & & 90 & \\
\hline & Nilai Terendah & & 50 & \\
\hline
\end{tabular}

Berdasarkan tabel 1. tersebut dapat dijelaskan sebagai berikut: Siswa yang mendapat nilai 90 sejumlah 4 siswa atau 12,90 \%. Siswa yang mendapat nilai 80 sejumlah 13 siswa atau 41,94\%. Siswa yang mendapat nilai 70 sejumlah 4 siswa atau 
$12,90 \%$. Siswa yang mendapat nilai 60 sejumlah 6 siswa atau 19,35\%. Siswa yang mendapat nilai 50 sejumlah 4 siswa atau $12,90 \%$.

Selain capaian nilai dari tabel tersebut dapat diketahui tingkat ketuntasan yaitu siswa yang telah tuntas mencapai 21 siswa atau 67,75 sedangkan siswa yang belum tuntas sejumlah 10 siswa atau $32,25 \%$. Rata-rata kelas mencapai 72,26 . Walaupun rata-rata kelasnya sudah di atas KKM belum berarti bahwa kelas tersebut mencapai ketuntasan. Hal tersebut dapat dilihat dari ketuntasan kelas yang masih di bawah kriteria ketuntasan kelas yang sudah ditetapkan sebelunya yaitu $85 \%$. Dari tabel tersebut diketahui pula nilai tertinggi yang dicapai 90 dan nilai terendah 50 .

\section{Pengelolaan pembelajaran}

Memperhatikan hasil temuan-temuan pada saat pembelajaran maka perlu adanya perbaikan-perbaikan atau perlu ada perlakuan yang berbeda dengan siklus 1 . Perlakuan itu terkait dengan pengeloaan kelas maupun cara menjelaskan materi pelajaran. Terkait cara menyajikan pelajaran perlu adanya media yang membantu menjelaskan materi yaitu dengan menggunakan media peta konsep dan media elektronik laptop dan LCD. Artinya ketika guru menjelaskan materi tidak sekedar ceramah dan memberi tugas tetapi perlu dibuatkan media berupa peta konsep yang ditayangkan lewat media LCD. Sehingga dengan hadirnya media ini diharapkan mampu memperjelas penjelasan guru dan pada akhirnya bisa meningkatkan hasil pembelajaran. Terkait perlakuan pengelolaan kelas dilakukan hal-hal sebagai berikut:

a. Guru perlu lebih terampil dalam memotivasi siswa agar lebih jelas dalam menyampaikan tujuan pembelajaran. Dimana siswa diajak untuk terlibat langsung dalam setiap kegiatan yang akan dilakukan.

b. Guru perlu mendistribusikan waktu secara baik dengan menambahkan informasi - informasi yang dirasa perlu dan memberi catatan.

c. Guru harus lebih terampil dan bersemangat dalam memotivasi siswa sehingga siswa bisa lebih antusias.

\section{Siklus II}

Tabel 2 Hasil Tes Siklus 2

\begin{tabular}{|l|l|l|l|l|l|}
\hline No & Nikali $(\mathrm{x})$ & Frekuensi & $\left(\mathrm{x}^{*} \mathrm{f}\right)$ & Prosentase & Keterangan \\
\hline 1 & 100 & 5 & 500 & 16.13 & Tuntas \\
\hline 2 & 90 & 7 & 630 & 22.58 & Tuntas \\
\hline 3 & 80 & 15 & 1200 & 48.39 & Tuntas \\
\hline 4 & 70 & 1 & 70 & 3.23 & Tidak Tuntas \\
\hline 5 & 60 & 3 & 180 & 9.68 & Tidak Tuntas \\
\hline & & 31 & 2580 & 100.00 & \\
\hline & Rata-rata & 83.23 & & \\
\hline & Tuntas & 90,32 & 28 & \\
\hline & Tidak Tuntas & 9,68 & 3 & \\
\hline & Nilai Tertinggi & & 100 & \\
\hline & Nilai Terendah & & 60 & \\
\hline
\end{tabular}

Berdasarkan tabel 4.2 tersebut dapat dijelaskan sebagai berikut: Siswa yang mendapat nilai 100 sejumlah 5 siswa atau 16,13\%.Siswa yang mendapat nilai 90 sejumlah 7 siswa atau $22,58 \%$. Siswa yang mendapat nilai 80 sejumlah 15 siswa atau $48,39 \%$. Siswa yang mendapat nilai 70 sejumlah 1 siswa atau 2,33 \%. Siswa yang mendapat nilai 60 sejumlah 3 siswa atau $9,68 \%$.

Selain capaian nilai dari tabel tersebut dapat diketahui tingkat ketuntasan yaitu siswa yang telah tuntas mencapai 28 siswa atau $90,32 \%$ sedangkan siswa yang belum 
tuntas sejumlah 3 siswa atau 3,68\%. Rata-rata kelas mencapai 83,23. Rata-rata kelasnya sudah di atas KKM dan tingkat ketuntasan juga berada di atas kriteria yang sudah ditetapkan berarti bahwa kelas tersebut mencapai ketuntasan. Hal tersebut dapat dilihat dari ketuntasan kelas sudah di atas kriteria ketuntasan kelas yang sudah ditetapkan sebelumnya yaitu $85 \%$. Dari tabel tersebut diketahui pula nilai tertinggi yang dicapai 100 dan nilai terendah 60. Selama proses belajar mengajar guru telah melaksanakan semua pembelajaran dengan baik. Meskipun ada beberapa aspek yang belum sempurna, tetapi prosentase pelaksanaannya untuk masing- masing aspek cukup besar. Kekurangan pada siklus - siklus sebelumnya sudah mengalami perbaikan dan peningkatan sehingga menjadi lebih baik. Hasil belajar siswa pada siklus II mencapai ketuntasan.

\section{Pembahasan}

Melalui hasil penelitian ini menunjukkan bahwa pembelajaran Kooperatif Learning dengan model student team achievement divisions (STAD) positif dalam meningkatkan prestasi belajar siswa. Hal ini dapat dilihat dari semakin mantapnya pemahaman siswa terhadap materi yang disampaikan guru (ketuntasan belajar meningkat dari siklus I, dan II) yaitu masing-masing 67,75 \% dan 90,32\%. Pada siklus II ketuntasan belajar siswa secara klasikal telah tercapai.

Peningkatan keberhasilan juga adanya peningkatan dari rata-rata kelas. Ratarata kelas siklus 1 sebesar 72,26 dan pada siklus 2 sebesar 83,23. Peroleh nilai tertinggi dan terendah juga mengalami peningkatan siklus 1 nilai tertinggi 90 sedangkan nilai terendahnya 50. Sedangkan siklus 2 nilai tertinggi 100 sedangkan nilai terendah 60. Deskripsi perolehan nilai di atas dapat dilihat dalam tabel berikut:

Tabel 3 Perbandingan Hasil Tes Siklus 1 dan Siklus 2

\begin{tabular}{|l|l|l|l|}
\hline No & Aspek & Siklus 1 & Suiklus 2 \\
\hline & Rata-rata & 72.26 & 83.23 \\
\hline & Tuntas & $67,75 \% / 21$ & $90,32 \% / 28$ \\
\hline & Tidak Tuntas & $32,25 / 10$ & $9,68 \% / 3$ \\
\hline & Nilai Tertinggi & 90 & 100 \\
\hline & Nilai Terendah & 50 & 60 \\
\hline
\end{tabular}

Berdasarkan data di atas juga bisa ditampilkan dalam bentuk grafik sebagai berikut: 
Grafik 1. Perbandingan Hasil tes Siklus 1 dan Siklus 2

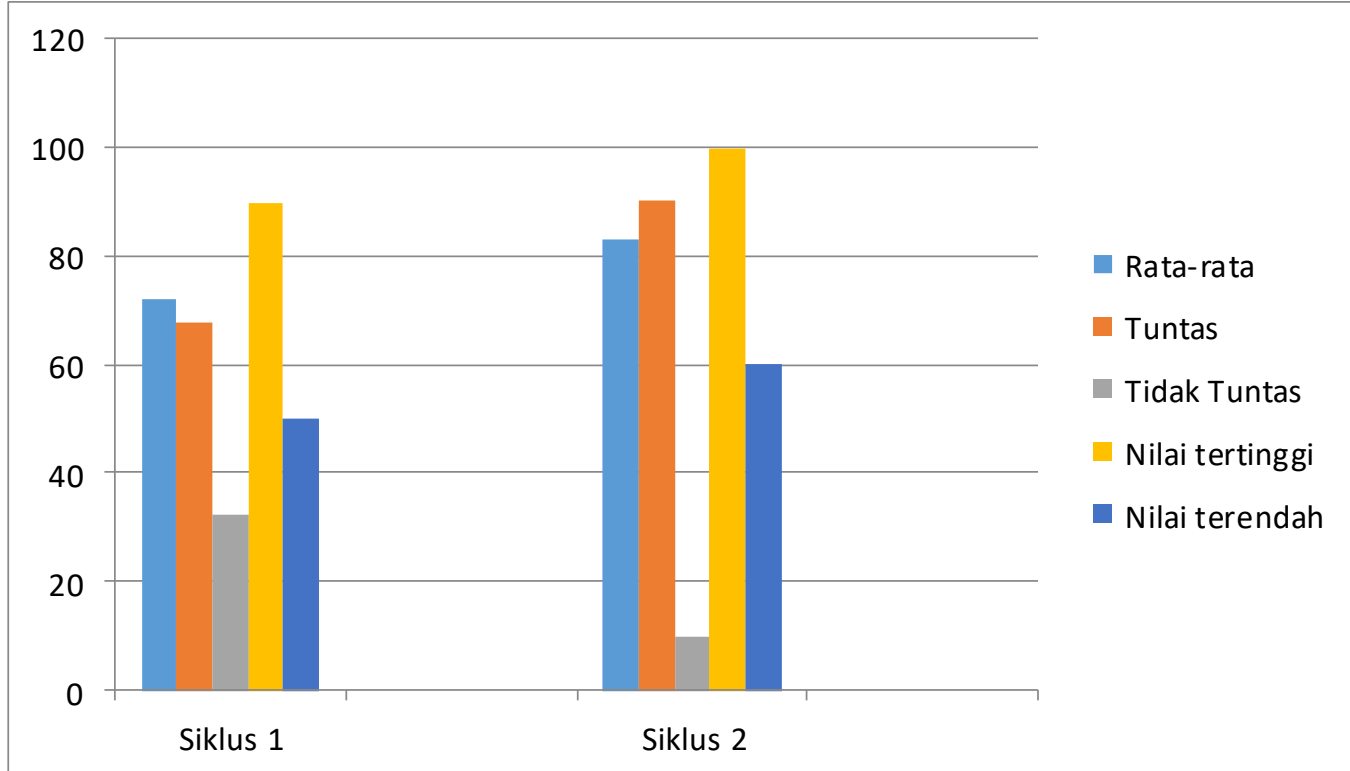

\section{KESIMPULAN}

Berdasarkan hasil pembahasan dan hasil analisis yang dilakukan maka dapat disimpulkan bahwa penelitian dengan judul peningkatan prestasi belajar PPKn materi menganalisis bentuk-bentuk kerja sama menggunakan model student Team achievement division (STAD) terbukti menunujukkan meningkatkan prestasi belajar siswa. Hal ini dapat dilihat dari semakin meningkatkannya ketuntasan belajar mulai dari siklus I ke II) yaitu Siklus 1 sebesar $67,75 \%$ atau 21 siswa dan siklus 2 sebesar $90,32 \%$ atau 28 siswa. Peningkatan keberhasilan juga adanya peningkatan dari ratarata kelas. Rata-rata kelas siklus 1 sebesar 72,26 dan pada siklus 2 sebesar 83,23. Peroleh nilai tertinggi dan terendah juga mengalami peningkatan siklus 1 nilai tertinggi 90 sedangkan nilai terendahnya 50. Sedangkan siklus 2 nilai tertinggi 100 sedangkan nilai terendah 60 .

\section{DAFTAR RUJUKAN}

Arikunto, S. 2010. Prosedur Penelitian: Suatu Pendekatan Praktik (Edisi Revisi). Jakarta: Rineka Cipta.

Bern. R.G. and Erickson,P.M. 2001. Contextual Teaching and Learning The Highligh Zone:Reseach@Work No.5(online) Tersediahttp://wwwnccte.org/ publication/infosynthesis/highlighzone/highlight5/index.asp.

Depdiknas. 2003. Kurikulum 2004 Standar Kompetensi Sekolah Dasar. Jakarta: Depdiknas.

Departemen Pendidikan Nasional, Pusat Bahasa.2008.Kamus Bahasa Indonesia.Jakarta

Dess, Robert L.1991.The Role of Cooperative Learning in Increasing Problem Solving Ability in a College Remedial Course (diterjemahkan oleh Isjoni.2009), Journal for Reseach in Mathematics Education.

Dimyati dan Mudjiono. 2006. Belajar dan Pembelajaran. Bandung.: Alfabeta.

Dirjen Dikdasmen, 1989. Pendidikan Pancasila. Jakarta:Dirjen Dikdasmen Depdiknas.

Permendiknas No 22 Tahun 2006 Tentang Standar Isi. Jakarta : Depdiknas

Slavin, E. Robert. 2010. Cooperative Learning Teori Riset dan Praktik. Bandung: Nusa Media. 
Sudjana, Nana. 2009. Penilaian Prestasi Proses Belajar Mengajar. Bandung: PT. Remaja Rosdakarya.

Sugihartono, dkk. 2007. Psikologi Pendidikan. Yogyakarta: UNY Press.

Undang-undang Nomor 2 Tahun 1989 pasal 39 ayat (1) tentang Sistem Pendidikan Nasional.

------2009. Amandemen UUD 1945. Yogyakarta:New Merah Putih.

Undang-Undang No.3 Tahun 2002 Pasal 1Tentang Pertahanan Negara

Wiriaatmadja, R. (2008), Metode Penelitian Tindakan Kelas, Bandung: PT Remaja Rosdakarya. 